\title{
アマルガム封入電球形蛍光ランプの水銀の振舞い
}

\author{
正会員 伊藤 秀徳* 正会員 依藤 孝** \\ 正会員尾岸和久* 専門会只井上 昭浩*

\section{Mercury Behaviors in a Compact Fluorescent Lamp With Amalgam} \\ Hidenori Itō (Member), Takashi Yorifuji (Member), \\ Kazuhisa Ogishi (Member) and Akihiro Inouye (Fellow Member) \\ (Toshiba Corp.)
}

\begin{abstract}
Some mercury behaviors in a compact fluorescent lamp with amalgam have been analyzed. The discharge tube is doubly folded. The main amalgam is contained in an exhaust tube and auxiliary amalgams are near the electrodes.

The results are as follow.

(1) The amount of In coating on the auxiliary amalgam flag influences luminous build-up characteristics of the lamp.

(2) After switching the lamp off, its mercury vapor diffuses from main amalgam to auxiliary amalgams.

(3) The mercury weight in auxiliary amalgam increases in proportion to the square root of $\mathrm{T}$ ( $\mathrm{T}$; total time lapse after switching off).

(4) The lamps mercury vapor pressure becomes minimum around forty cinutes after switching the lamp off.
\end{abstract}

\section{1. 緒言}

近年, 電球ソケットにそのまま装着できる電球形蛍光ランプが 開発され1)，さらに性能向上のための検討が盛んである゙2. 一般 に, 電球形蛍光ランプは, 発光管を点灯回路と一体化して電球口 金付きのケースに収容している.この構造のランプは発光管の温 度が一般の巣光ランプより著しく上昇し，效率の低下が大きくな る ${ }^{3)}$ そのため発光管の効率向上のための種々の工夫が講じられ ているが4)，その一つとしてアマルガムを使ら方法がある2). こ れは，アマルガムによって管内の水銀蒸気压を制御する方法であ り，発光管の温度が高温となっても高い効率を得ることが可能で ある・

このアマルガム封入ランプは，アマルガムの温度が上昇するの に時間を要するため，始動後の光束立ち上がりが遅くなるという 欠点がある ${ }^{2}$. これは定常点灯時の水銀蒸気压を制御するアマル ガム（主アマルガム）の泳か，始動直後に必要な水銀蒸気压を 補う補助アマルガムを電極近傍に設けることで改善される

アマルガム封入電球形蛍光ランプは, 一般の水銀だけのランプ に比べて点灯直後の光束の変化が複雑である. したがって点灯直 後の水銀の挙動を左右し, 光束の立ち上がりに影響与る補助アマ ルガムの特性を明らかにする必要がある.

* 東芝光源開発研究部 $* *$ *東芝照明技術部 厂237 横徐賀市船越町 1-201-1

201-1 Funakoshicho 1 chome, Yokosuka, Kanagawa 237 Japan 本諭文内容は, 昭和60年 3 月の照明学会全国大会で発表したものである.

\section{2. アマルガム封入電球形蛍光ランプの構成}

実験に用いたランプの全体構造を図 1 に示す．安定器はプラ スチックのボックスに収容し，発光管と安定器とは熱交換を少な くした構暹としている.グローブの材質はポリカーボネイトであ り, その外径は $110 \mathrm{~mm} \phi$, 発光管の外径は $17.5 \mathrm{~mm}$, 発光管全 長は $330 \mathrm{~mm}$ である. 発光管内壁には蛍光体を塗布し, 始動用希 ガスとしてアルゴン（479 Pa）を封入している. 電極近傍の構造 を図 2 に拉大して示す. 主アマルガムを片側の排気管内に, 補 助アマルガムを両方の電極に固定している. ランプ定格点灯時の 発光管入力電力は $12.5 \mathrm{~W}$, 発光管電流は $0.27 \mathrm{~A}$ である.

主アマルガムは, 点灯安定時の管内の水銀蒸気压を制御するる のであり，その満たすべき条件としては，第 1 亿定常点灯時のア マルガム温度で光出力が最大となる最適水銀蒸気压を示すこと,

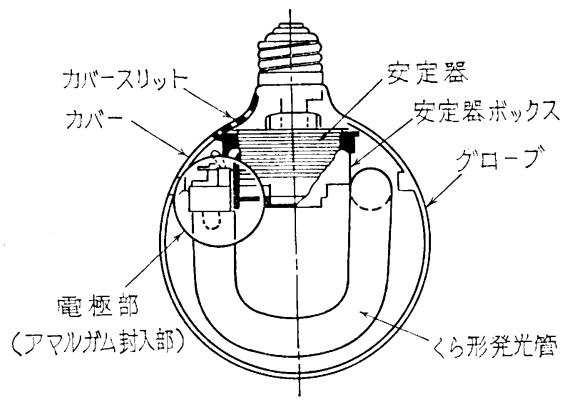

図 1 フマルガム封入沓球形监光ランプの 全休㭬造図 


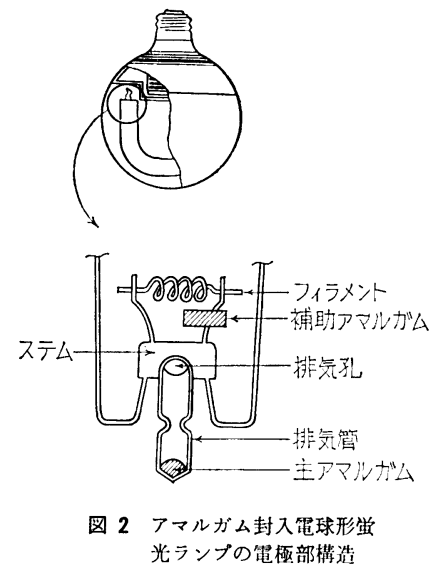

第 2 にできるだけ広い温度範囲にわたって, 水銀蒸気压の变化を 制御できることが必要である. 本実験に使用した主アマルガムは 上記 2 条件を考虑して Bi-In-Hg 系アマルガムを採用した．定常 点灯時のアマルガムの動作温度は $80 \sim 90^{\circ} \mathrm{C}$ であり, 主アマルガ 么の封入量は約 $70 \mathrm{mg}$ である. 主アマルガム中の含有水銀量がラ ンプ特性および水銀消費によるランプ寿命を左右するため6)， そ れを保証するに十分な水銀量（約 $3 \mathrm{mg}$ ）を含儿でいる. 図 3 に このランプの周困温度特性を示す. 主アマルガムの効果により水 銀だけを封入したランプに比べて，広い温度範囲にわたって安定 した光出力を得ることができる.

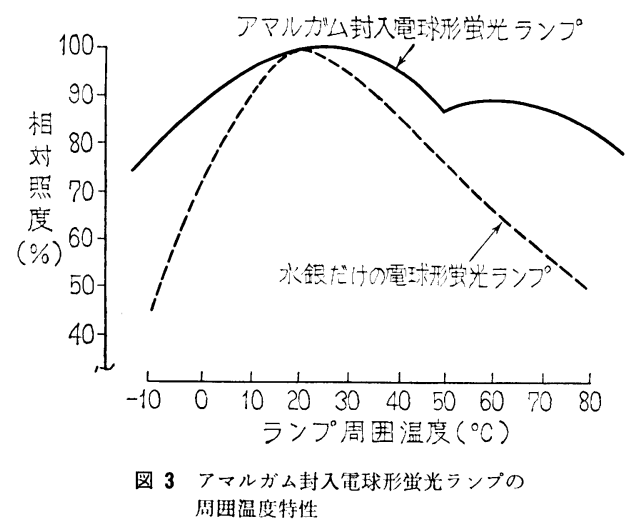

\section{3. 補助アマルガム機能}

\section{1 光束立ち上がり特性の改善}

アマルガム封入ランプは, 水銀蒸気圧が純水銀の蒸気压より低 いといら特性を利用しているため5), ランプ点灯後, 定常状態に 安定するまでの光束の立ち上がりが遅くなる．このような始動時 の光束の立ち上がりを改善するために, 定常点灯時の水銀蒸気压 を制御する主アマルガムのほかに，始動時に必要な水銀蒸父圧を 補う補助のアマルガムを用いる必要がある45).

図 4 Kアマルガム封入電球形蛍光ランプの光束立ち上がり特 性を示す．補助アマルガムのないランプの光束立ち上がりは, 主 アマルガム設置部分の温度上昇に対応している. それゆえ，光束 の安定時間は20分以上を要する。一方, 補助アマルガムを用いた ランプは，補助アマルガムとして基体金属の表面に In- $\mathrm{Hg}$ を付 着して用いている．基体金属にはモリブデン簿（大きさ $2.5 \times 6.5$ $\mathrm{mm}$, 厚み $30 \mu$ )を用いた. このランプは, 始動直後補助アマル ガムの温度が急速に上昰するため水銀が放出され，点灯後 30 秒で

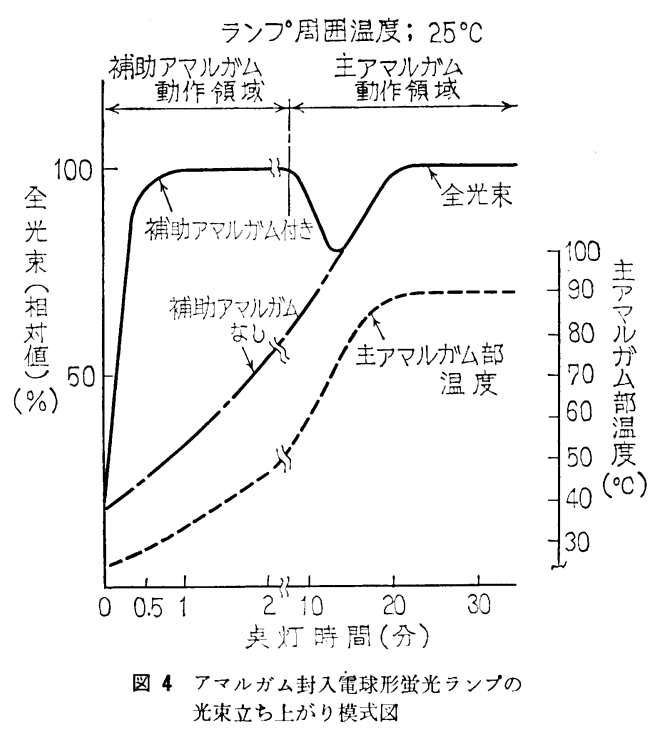

$80 \%$ 以上の光束を得， 1 分以内に $100 \%$ の光束を得る. その後管 内の水銀は, 主アマルガムへ吸着されることにより若干光束が減 少するが，主アマルガムの温度上昇とともに再び光束が上昇す る. したがって点灯初期の $2 \sim 3$ 分間は補助アマルガムの動作領 域であり，それ以降は主アマルガムの動作領域である.

\section{2 補助アマルガムの条件}

図 5 に補助アマルガムとして In-Hg を用い, 基体金属として モリブデン管（大きさ $2.5 \times 6.5 \mathrm{~mm}$ ，厚み $30 \mu$ ）を用いて，基体 金属上の In 付着量と光束立ち上がり特性を調べた結果を示す. In は電気めっき法で付着させた. ランプ構造は図 1 に示すとお りのものである. 主アマルガムと補助アマルガムの距離は $25 \mathrm{~mm}$ とし, 補助アマルガムと電極 (フィラメント) 間の距離は $2.5 \mathrm{~mm}$ とした. ランプは測定前に電源電压 $100 \mathrm{~V} て ゙ 1$ 時間点灯し, 消灯 状態で10時間放置した，点灯時のランプ周囲温度は $25^{\circ} \mathrm{C}$ で電源 電压 $100 \mathrm{~V}$ を印加し, 点灯30秒後の光束の安定時の光束に対する 比を調べた. その結果, 補助アマルガムに使用する In 量の最適 值が存在し, その值は本史験の埸合, 一つの補助アマルガムあた り $1 \mathrm{mg}$ であることが判明した。 これは次のように説明できる.

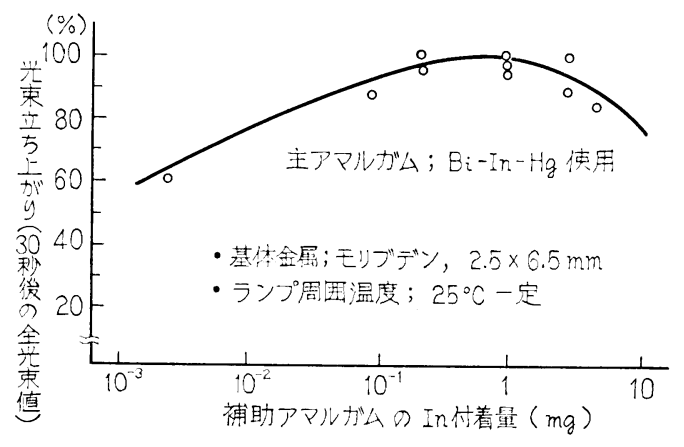

図 5 補助アマルガムの In 付着量と光束立ち上がり

すなわち, In 付着量が適正值より少なくなると相対的に In- $\mathrm{Hg}$ の $\mathrm{Hg}$ 比率が增大し, 同一温度に怙ける主, 補助アマルガムの蒸 気压垭が小さくなる．消灯時の浮遊水銀は蒸気压の最小の場所へ 集まるが, 主, 補助アマルガムの蒸気压差が小さくなると相対的 に補助アマルガムへ吸着される水銀量が少なくなり, 光束の立ち 上がりが悪くなる.一方 In 付着量が適正值より多くなると相対 的に In-Hg の $\mathrm{Hg}$ 比率が減少し, 蒸気圧が高温下でも低くなる. 
この場合, ランプを点灯すると補助アマルガムはフィラメントの 熱により加熱され，補助アマルガム中の水銀が放出されるが，蒸 気压が低いため水銀放出量が少なく，光束立ち上がりが覀くな る.このような理由で In 量の最適值が存在することになる.

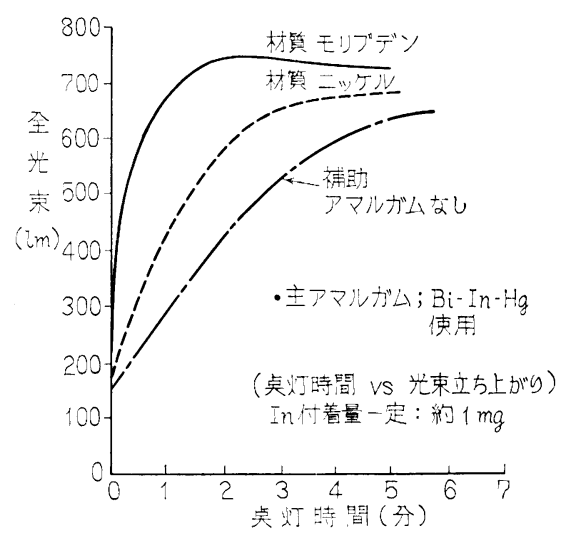

図 6 補助アマルガムの蕉体金属と 光束站ち上がり( I )

発光管外径 $17.5 \mathrm{~mm}$ ，管辰 $330 \mathrm{~mm}$ ，封入 ガス: Ar $479 \mathrm{~Pa}$ グローブ径 $110 \mathrm{~mm}$, 発 光管入力電力 $12.5 \mathrm{~W}$

図 6 亿補助アマルガムの基体金属を变えた場合の光束立ち上 がりを示す. ランプ满造は図 1 と同一であり，発光管は外径 17.5 $\mathrm{mm}$ ，管全長 $330 \mathrm{~mm}$ であり，管内に始動用希ガスとしてアルゴ ン（479 Pa）を封入している. 補助アマルガムは In-Hg を使用 し，一つの補助アマルガムあたりの In 付着量は約 $1.0 \mathrm{mg}$ であ る. 主アマルガムは Bi-In-Hg $(70 \mathrm{mg})$ を用いている. 主, 補助 アマルガムの設谓位置は図 2 と同一である。基体金属にはモリブ デン簿（大きさ $2.5 \times 6.5 \mathrm{~mm}$ ，厚み $30 \mu$ ）と二ッケル板（大きさ $2.5 \times 6.5 \mathrm{~mm}$ ，厚み $100 \mu$ ）を用いた。 な招基体金属の面積を一 定としている．材質により厚みが変わっているのは，その材質の 強度, 加工性を考えて，厚みを選択したためである．ランプは測 定前に 1 時間以上定常点灯し，消灯状態で10時間放泻した．点灯 30秒後では，モリブデン管を用いた発光管はニッケル板のものよ り約 2.9 倍, 1 分後では約 2.0 倍の光束立ち上がりを示している. この光束立ち上がりの差は盐体金属の熱容量の差で，次のように 説明される。すなわち，基体金属の温度上昇は(1)式で示される。

$$
\Delta T=\frac{Q}{m C_{p}}
$$

ここで， $\Delta T$ は基体金属の温度上昇 $\left({ }^{\circ} \mathrm{C} \cdot \mathrm{s}^{-1}\right) ， Q$ は基体金属へ 与兄られる熱量 $\left(\mathrm{kcal} \cdot \mathrm{s}^{-1}\right), m$ は基体金属の質量 $(\mathrm{g}), C_{p}$ は 基体金属の比熱 $\left(\mathrm{cal} \cdot \mathrm{g}^{-1} \cdot{ }^{\circ} \mathrm{C}^{-1}\right.$ ) である. 基体金属へ与兄られる 熱量はフィラメントからの加熱であり常に一定とすると，基体金 属の温度上昇は，その熱容量に反比例する. 本实験の試料で熱容 量の近数の值を比較すると，モリブデン簿はニッケル板の 約 5.0 倍となり, 点灯初期の雨者の立ち上がり所要時間比 2.9 倍より少 し大きいが，比較的近い值を示している，すなわち，基体金属の 選定にあたっては熱容量，すなわち比熱と質量のできるだけ小さ いものを選定することが望ましい。

図 7 に補助アマルガムの点減特性を示す. ランプ条件は図 6 と同一である. 電極部の構造も図 2 と同一であり, 補助アマルガ ムは両方の電極に固定している. 試験は定格電压 $100 \mathrm{~V} て ゙$ 行な い, ランプ点減サイクルは 30 秒点灯, 30 秒消灯で行なった. ラン

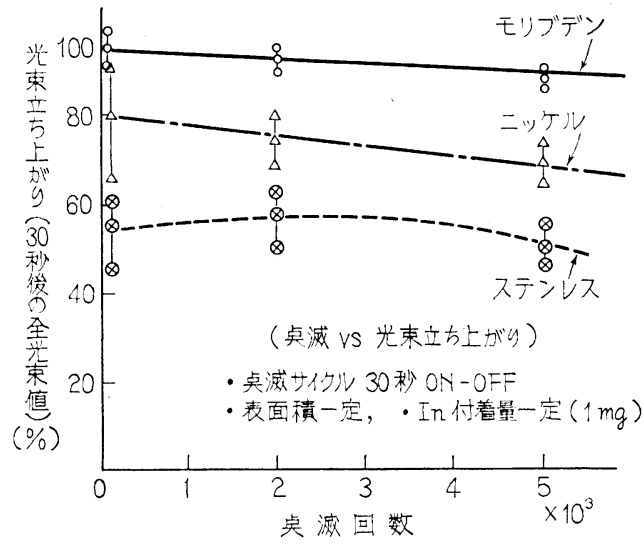

図 7 補助アマルガムの基体金属上光束立ち上 がり(II)

プ点灯方向は口金上向き状態であり, 点減試験中のランプ周囲温 度は $20 \sim 23^{\circ} \mathrm{C}$ で苛った．特性評価時点は，点隇試験前 2,000 回， および 5,000 回点滅後の 3 種類とした. 各々点減試験後, ランプ 周囲温度 $25^{\circ} \mathrm{C}$ で 1 時間点灯し, 消灯状態で 10 時間放置した後, ランプ周囲温度 $25^{\circ} \mathrm{C}$ で点灯し, 始動後 30 秒時点の光束立ち上が りを比較した．基体金属には，モリブデン䇴（大きさ $2.5 \times 6.5$ $\mathrm{mm}$, 厚又 $30 \mu$ ), ニッケル板(大きさ $2.5 \times 6.5 \mathrm{~mm}$, 厚み $100 \mu$ ), ステンレス板（大きさ $2.5 \times 6.5 \mathrm{~mm}$, 厚み $150 \mu$ )を使用した. 一つの基体金属あたりの In 付着量は約 $1.0 \mathrm{mg}$ である。この場 合子，四6 と同様に点隇前の光束立ち上がりの差は，基体金属の 熱容量の爯で説明できる. 各々の基体金属の熱容量は, モリブデ ン簿 $0.31\left(\mathrm{cal} \cdot{ }^{\circ} \mathrm{C}^{-1}\right)$, ニッケル板 $1.53\left(\mathrm{cal} \cdot{ }^{\circ} \mathrm{C}^{-1}\right)$, ステンレス 板 $2.30\left(\mathrm{cal} \cdot{ }^{\circ} \mathrm{C}^{-1}\right)$ である. 点減前の光束立ち上がりは, 基体金 属の熱容量の逆数の值の順, すなわちモりブデン馢, ニッケル 板, ステンレス板の順に速い. 点隇後の光束立ち上がり特性の劣 化は, モリブデン箈使用の場合 5,000 回点減後で約 $5 \%$, ニッヶ ル板使用の場合は約 $8 \%$ である.一方, 点隇試験前後に括活る安 定時全光束は平均約 $5 \%$ の低下である. 点減少化には, 蛍光体の 劣化, 電極エミッタの飛散, そして補助アマルガムインジウムの 飛散などが考えられる.これらの分離㴍俩は困難である.しかし ながら, 光束立ち上がりの劣化が $5 \%$ 程度であることから補助ア マルガム機能の低下は少ないと判断できる. ニッケル板使用の場 合, モリブデン簿使用の場合に比較し劣化が若干大きい理由とし ては, 次の要因も挙げることができる.

すなわち，インジウムとニッケルが合金を形成する可能性を有 することである. ランプ点灯中, 補助アマルガムはフィラメント の加熱により高温にさらされる. 特にニッケルの場合, 高温にな ると表面層の In の一部が合金 In-Ni を形成し7), 永面層に必要 なInの最適值からはずれてくるだめと推测される.

したがって上記を考虑すると, ランブ始動中や点灯中の高温雾 囲気でも In とほとんど合金を作らない材質を選定する必要があ る.モリブデンは, 高温雲囲気でも安定であり, 此熱も小さくか つ箔状に加工したものが容易に入手できることから，基体金属と してはすぐれた材質であるといえる.

\section{4. 消灯後放置時間と水銀蒸気圧}

\section{1 消灯後の管内水銀量の変化}

ランプ消灯後の管内の浮遊水銀蒸気は, 蒸気压の低いアマルガ ムへ吸着される，本実験では消灯後経過時間に対する管内各部の 
水銀量の変化を測定した．ランプ構造および電極部の構造は図 1 および図 2 と同一である. ランプ発光管の外径は $17.5 \mathrm{~mm}$, 管全. 長は $330 \mathrm{~mm}$ であり，管内に始動用希ガスとして $\mathrm{Ar}(479 \mathrm{~Pa})$ を封入している. ランプの発光管入力は $12.5 \mathrm{~W}$ ， 発光管電流は $0.27 \mathrm{~A}$ である. ランプは周囲温度 $25^{\circ} \mathrm{C}$ で 4 時間連続点灯した. 試験電圧は $100 \mathrm{~V}$ であり, 点灯方向は口金上向きである。したが って点灯中の主, 補助アマルガムの位置関係は, 主アマルガムが 補助アマルガムの上方約 $25 \mathrm{~mm}$ の位置にある. 点灯後周囲温度 $20 \sim 25^{\circ} \mathrm{C}$ で口金上向き方向のまま消灯放圆した，消灯放置時間 は10分, 30 分, 60 分 (1 時間), 240 分 (4 時間), 3, 900 分 (65 時間）の 5 種類とした. 管内の水銀量の測定は, 各々のランプを 破壊し, 主, 補助アマルガム部分とその他の部分に 3 分割して水 銀を回収しジチゾン吸光光度法で分析した。

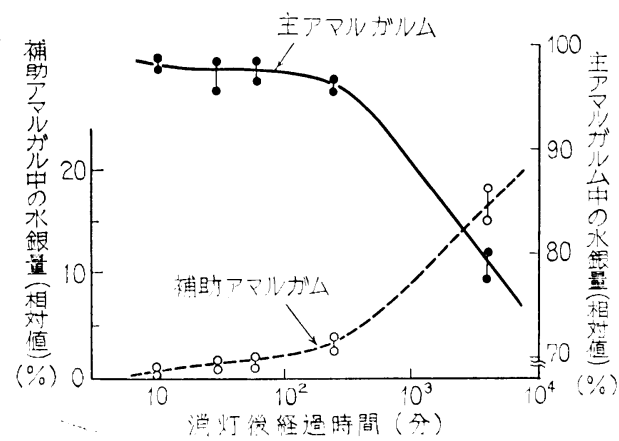

図8 消灯時の主, 補アマルガム中の水銀量 の変化 (相対值)

图 8 に消灯後経過時間に対する管内の各部の水銀量変化を相 対值で示す．水銀量相対值は管内の総水銀量に対する比率（\%) で示す. 消灯後, 時間経過とともに主アマルガムの水銀量は減少 し, 補助アマルガムの水銀量は增加する ${ }^{8}$.

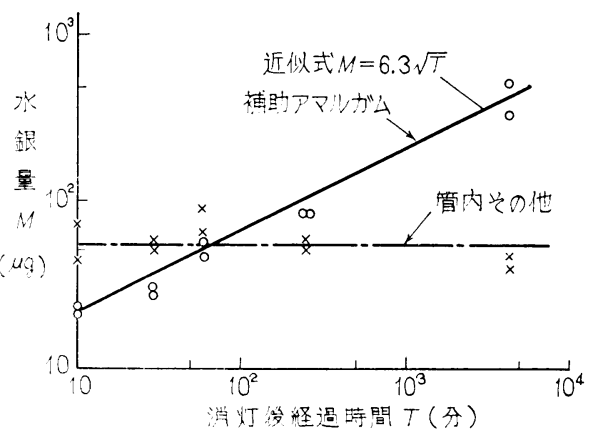
图 9 消灯眝の主, 補アマルガムへの吸着
水銀们の変化

図 9 には補助アマルガムへ吸着される水銀量および主, 補助 アマルガム以外の管内水銀量の消灯後の時間による変化を示す.

これによると主, 補助アマルガム以外の管内の水銀量はほとんど 一定の傾向を示している. 図 8 上り消灯後, 少なくとも3,900 分 (65 時間) までは主, 補助アマルガム間で水銀の移動が行なわれ ていることがわかる.

さて図 9 から補助アマルガムへ吸着される水銀量は, 次の実験 式で示される.

$M=6.3 \sqrt{T}$ .$(2)$

ここで, $M$ は補助アマルガムへ吸着される水銀量 $(\mu \mathrm{g}), T$ は 消灯後の経過時間（分）を表わす.

\section{2 消灯時の管内水銀蒸気圧の变化}

次に消灯時の主, 補助アマルガムの水銀濃度が管内の水銀蒸父 压に及ぼす影罄を調べた，消灯時の管内の水銀は，主，補助アマ ルガムへ吸着され，消灯時間とともにその水銀濃度は変化し，管 内の水銀蒸気压を左右する，そこで消灯時の両者の変化を対応さ せてみる.

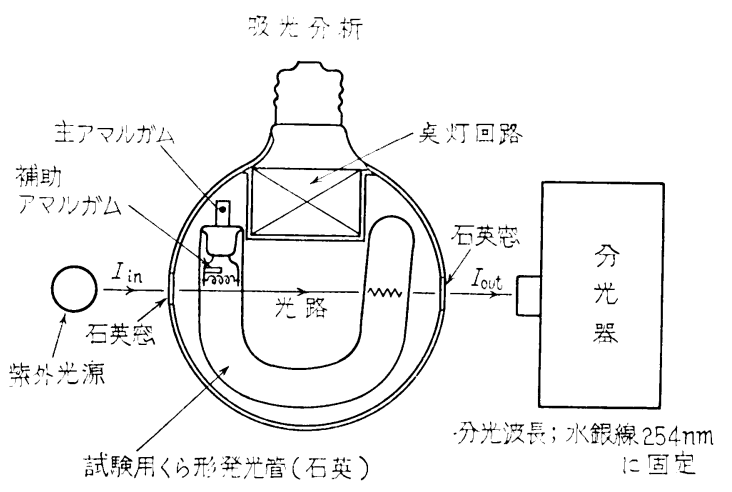

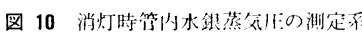

管内の水銀蒸気压変化は，图 10 に示す測定系で測定できる. 試験用発光管は，蛍光体を塗布しない透明な石茫製バルブを用い た. 発光管の外径は $17.5 \mathrm{~mm}$, 管全長は $330 \mathrm{~mm}$ であり, 管内に $\operatorname{Ar}(479 \mathrm{~Pa})$ を封入している. ランプ構造拈よび電極部の構造は 図 1 および図 2 と同一である. 補助アマルガムとして In-Hg を用 いた．補助アマルガムの基体金属はモリブデン簿（大きさ $2.5 \times$ $6.5 \mathrm{~mm}$ ，厚み $30 \mu$ )を用い，Inの付着量は約 $1.0 \mathrm{mg}$ である. 主 アマルガムとして Bi-In-Hg を約 $70 \mathrm{mg}$ 封入している. 主, 補助 アマルガムの位圈関係は, 図 5 〜図 9 の場合と同一である. グロ ーブには，紫外放射を透過するための石英空を光路に設けてい る. 上記構造のランプを，測定前に $25^{\circ} \mathrm{C}$ 雾囲気中に 4 時間口金 上向きで点灯した，点灯安定時の発光管入力電力は $12.5 \mathrm{~W}$, 発 光管電流は $0.27 \mathrm{~A}$ である. ランプ消灯後, 殺菌ランプを 柴外光 源とし水銀共嘶線 $253.7 \mathrm{~nm}$ を発光管に照射し，その透過光の強 度を測定することにより，消灯後の管内の水銀蒸众圧变化を相対 值として求めた．ランプ消灯後のランプ周用温度は $25^{\circ} \mathrm{C}$, 口金 上向き状態で放罝した．ランプ消灯中の入射光の強度と透過光の 強度には(3)式が成立する ${ }^{9}$.

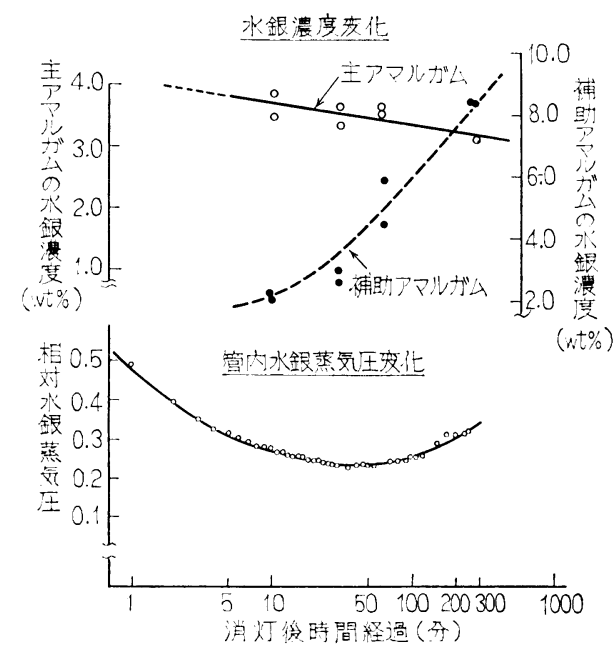

図 11 管内水銀蒸気压の変化 


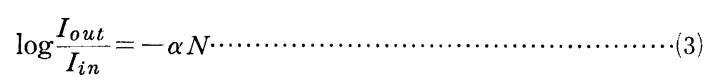

ここで， $I_{\text {in }}$ は入射光の强度， $I_{\text {out }}$ は透過光の強度， $\alpha$ は定 数，Nは水銀原子の密度を表わす，入射光と透過光の強度比を求 めれば，水銀原子の濃度すなわち水銀蒸父压の相対值が求まる. 消灯後の時問に対する相対水銀蒸気压の変化を図 11 に示す．同 㘠には, 前実験 (4.1) で得られた主, 補助アマルガムの水銀濃度 の変化も対比して示す，管内の水銀蒸気压は，消灯後時間ととも に減少し最低值を示した後上昇している. 一方, 主アマルガムの 水銀濃度は消灯時間とともに減少し，補助アマルガムのそれは增 加している，消灯後の管内水銀蒸父任は，主，補助アマルガムの 温度と水銀濃度に左右されていると考えられ，雨者を対比すると 少なくとも管内水銀蒸気圧が最低值を示すまでは, 主アマルガム が関与し, 最低值を示した後の水銀蒸気圧は, 補助アマルガムが 関与していると推察される.

\section{5. を め}

アマルガム封入電球形蛍光ランブは, 光束立ち上がり改善用と しての補助アマルガムを必要とする．本論文では補助アマルガム に必要な特性を求め, 水銀の移動とそれに基つう管内水銀蒸全住 変化を求めた。 その結果，まず基体金属の材質，補助アマルガム の付着量によって光束立ち上がり性能が左右されることがわかっ た，基体金属としては，熱容量が小さく高温でも安定である材質 が望ましい. 補助アマルガムに In-Hgを用いる場合, 面積一定 (約 $16 \mathrm{~mm}^{2}$ ) の条件では，一つの補助アマルガムあたりの In 付 着量 $1.0 \mathrm{mg}$ 前後に最適值が存在する.

補期アマルガムへ吸着される水銀量は, 消灯後経過時間の平方 根に比例して增加して招り, 主アマルガムから補助アマルガムへ
水銀が移動していることが判明した．消灯時における管内の水銀 蒸気压は主, 補助アマルガムの水銀濃度の变化に対応し, 消灯時 間40分前後で最低值を示す.水銀蒸父圧が最低值を示すまでは, 主アマルガムが管内の水銀蒸気圧を左右し，最低值を示した後の それは補助アマルガムが左右している.

\section{参考文 献}

（1）亀井, 林, 長田, 池田, 高野: 電球形蛍光ランブ「ネオボ ール」, 東芝レビュー 35-8（昭55）679 681

（2）伊藤, 林, 佐藤, 長田：ネオボールの効率向上, 東芝レビ ュ一 39-11（昭59） 995〜998

(3) 花田, 亀井, 汇原, 長田, 小田, 高野: 新しい電球形蛍光 ランプネオボール，東芝レビュー 37-2（昭57）96〜100

(4) Bouwknegt, A.: Compact Fluorescent Lamps, J. Illum Engng. Soc. 11-4 (1982) 204

(5) Bloem, J., Bouwknegt, A. and Wesselink, G. A.: Some New Mercury Alloys for Use in Fluorescent Lamps, J. Illum. Engng. Soc. 6-3 (1977) 141

（6）広田泰輔：蓝光ランプへの水銀合金の応用, 照学誌 68-2 (昭59) $77 \sim 82$

(7) Hansen, M.: Constitution of Binary Alloys, Metallurgy and Metallurgical Engineering Series, Mc GRAWHILL BOOK COMPANY, NEW YORK (1958)

（8）小野, 松野, 村山：分離内管方式電球形蛍光ランプの光束 立ち上がり特性, 照学誌 68-10（昭59） 524〜 527

(9) 武内次夫, 鈴木正己：原子吸光分光分析, 南汇堂 (昭53) 